\title{
Assessment of Clayey Peloid Formulations Prior to Clinical Use in Equine Rehabilitation
}

\author{
Carla Marina Bastos ${ }^{1,2, *}$, Fernando Rocha ${ }^{1} \mathbb{1}$, Ângela Cerqueira ${ }^{1}$, Denise Terroso ${ }^{1}$, \\ Cristina Sequeira ${ }^{1}$ and Paula Tilley ${ }^{3}$ (i) \\ 1 GeoBioTec Research Centre, Department of Geosciences, University of Aveiro, 3810-193 Aveiro, Portugal; \\ tavares.rocha@ua.pt (F.R.); angelamcerqueira@ua.pt (Â.C.); laraterroso@ua.pt (D.T.); csequeira@ua.pt (C.S.) \\ 2 Exatronic, Lda, 3800-373 Aveiro, Portugal \\ 3 CIISA - Centre for Interdisciplinary Research in animal Health, Faculty of Veterinary Medicine, University of \\ Lisbon, 1300-477 Lisbon, Portugal; paulatilley@fmv.ulisboa.pt \\ * Correspondence: a4872@ua.pt; Tel.:+351-234-370357
}

Received: 31 March 2020; Accepted: 9 May 2020; Published: 12 May 2020

check for

\begin{abstract}
Clays are natural ingredients used to prepare therapeutic cataplasms suitable for topical application. The knowledge about these formulations and their preparations to be applied on humans and animals has been orally transmitted since ancient times. Several empirical methods using clays have demonstrated fast and effective results in the reduction of the inflammatory response and the formation of edemas in horse limbs. The use of traditional and alternative medicine, such as pelotherapy, is now becoming more popular in veterinarian medical practice, alone or combined with other therapies in horse muscle and tendon rehabilitation. This study characterizes the use of commercial equine clays and an old therapeutic clay cataplasm formulation, using acetic acid, to treat tendon injuries in horses. This work might contribute to a major database characterization of clays used empirically on equine health, the potential of dermal absorption, the risks of exposure to some toxic elements, and safety assessment for these formulations. The present study was carried out to characterize the suitability of four commercial equine clays (Group II) and a protocoled healing mixture: "clay acetic acid cataplasm", (Group III), to treat tendon injuries in horses. In this mixture, three conventional "green" clays (Group I) without any mineralogical specificity were used and blended with acetic acid. The mineralogical composition was determined through X-ray powder diffraction and X-ray fluorescence data. To determine the performance of the samples, cooling kinetics, oil absorption, expandability, and specific surface area were measured. According to the mineralogical composition, Group I was mainly composed of carbonates and silicates, while Group II was much richer in silicates with the main clay minerals kaolinite and illite. Group II exhibited the highest values for $\mathrm{As}, \mathrm{Pb}, \mathrm{Cr}, \mathrm{Ni}$, and $\mathrm{Zn}$, considered potentially toxic. Both groups showed low cation exchange capacities and exchanged mainly $\mathrm{Ca}^{2+}$, with the exception of VET.1 and VET.7, which also highlight $\mathrm{Na}^{+}$, and VET.5 and VET.6, which have $\mathrm{K}^{+}$as an exchangeable main cation. The addition of acetic acid (Group III) does not reveal any significant chemical changes. The results confirm that both clay groups are adequate for the therapeutic propose. They have good plastic properties (skin adherence), good oil absorptive capabilities (cleaning), and exchange an essential physiological element, calcium. Group II has prior industrial preparation, which is probably why it showed better results. Group I presented lower heat retention capacity and higher abrasiveness, which could be improved using cosmetic additives. The clinical benefit of the "clay acetic acid cataplasm" (Group III) could be the systemic anti-inflammatory effect established by the acetic acid.
\end{abstract}

Keywords: ethnoveterinary; pelotherapy; healing clays; quality control; equine limb injuries 


\section{Introduction}

It is well documented that clayey formulations have been important resources for human and animal health care, because of their therapeutic and curative properties, since the first records in history [1,2].

Several traditional veterinary practices use zootherapeutic resources in the health care of domestic animals, the medicinal value of which maintains its relevance in ethnoveterinary medicine (EVM), the scientific term for traditional animal health care [3]. Clay minerals and their healing powers in wild animals are well documented by the practice of eating clay (geophagy) for detoxification of the body and alleviation of gastrointestinal infections and are now being rediscovered [4]. Kaolin and smectitic clays are commonly used in animal nutrition as growth promoters and supplements for the treatment of gastrointestinal disturbances. The introduction of kaolin clay, as feed additive, to treat foals with "heat" diarrhea, caused by disturbances in the intestinal osmotic balance of the young horses succeeds well as an absorbent and as an anticaking agent, alleviating the severity and duration of foal heat diarrhea [5].

The veterinary industry responds to the equine market with specific clayey products, promoting them by their pharmacological effects. The clayey products tailored for lameness injury prevention are relevant indicators for the evaluation of the therapeutic impact of pelotherapy in equine health and product procurement.

The clays' efficacy for lameness or other musculoskeletal injuries on horses is free of regulatory compliance. Most of these clayey products are designed accordingly with requirements and specifications supported by specialized equine technicians.

The use of pelotherapy as a therapeutic modality is scientifically little explored in equine health, despite its recognition as a valid non-invasive therapeutic option.

There are a few veterinarian databases, designed to search for relevant studies and clinical trials reported by researchers, such as PubMed and IVIS Quick-Links. The AVMA Animal Health Studies Database (www.avma.org/findvetstudies) allows submission and search of studies for health care issues in dogs, cats, horses, or other animals. Using "horse" and "equine" as a keyword we did not find any issue related to the use of clays in equine rehabilitation.

Clay minerals are widely used in pharmaceutical formulations as excipients and because of their biological activities [6] and are used in cosmetics because of their physical and physical-chemical properties such as adsorption capacity, specific surface area, swelling capacity, and reactivity to acids [7].

Williams and Haydel (2010) made the distinction between "healing clays" and "antibacterial clays", which may cure several diseases only by their unique physical and chemical properties (e.g., high absorbance, surface area, heat capacity, exchange capacity, etc.) or by killing pathogenic bacteria [8].

The absorptive capabilities of clays have been explored in a variety of cosmetic and pharmaceutical formulations and as a contributor to the healing of diseases, as well as for their cation exchange capacity and extremely fine particle size, which are important properties for removing oils, secretions, toxins, and contaminants from the skin. Cation exchange experiments showed that the antibacterial component of the clay can be moved, implying the presence of exchangeable cations in the antibacterial process [8]. Studies made on a natural clay from the Colombian Amazon and compared to the standard reference of smectite and kaolinite showed chemical interactions that are detrimental to bacteria by absorbing nutrients (e.g., $\mathrm{Mg}, \mathrm{P}$ ) and by toxic metal supply (e.g., $\mathrm{Al}$ ) [9].

Humans and equine athletes share acute and chronic tendon injuries as the most common orthopedic affections, having similar structural (reparation) and functional (regeneration) recovery process. [10].

$\mathrm{Ca}, \mathrm{P}, \mathrm{K}$, and $\mathrm{S}$ play a pivotal role in both the growth and the degeneration of the collagenous bone-cartilage interface of articulating joints demonstrated on equine osteoarthritic lesions (metacarpophalangeal joint) by detecting variations of elemental presence, using Synchrotron radiation micro $\mathrm{X}$-ray fluorescence analysis [11]. 
The conservative veterinary therapy protocols include the same considerations as the human medicine protocols for orthopedic affections: cold applications, pressure-supporting bandages, controlled exercise, medicines to be injected, electrotherapy sessions, electromagnetic stimulation, ultrasound and laser therapy, or in an extreme clinical recommendation, surgical therapy [10]. Intra-articular (IA) administration of drugs in the treatment of musculoskeletal injuries has the objective of directing the drug delivery to the affected tissues and is commonly used by veterinarians and by Medical Physical Rehabilitation specialists. The use of corticosteroids or nonsteroidal anti-inflammatory drugs is common in racehorses and has become a problem for veterinarians due to the fact that the medicine could be masking a possible musculoskeletal condition and may contribute to injuries during competition [10,12]. Although there are a significant number of nonsteroidal anti-inflammatory drug (NSAID) formulations designed for the treatment of muscle and tendon traumatic conditions in human beings, when compared with the same problem in equine clinical practice, these formulations are more commonly used in horses. In vitro studies to evaluate and compare the penetration of diclofenac, a common NSAID designed for human application, revealed a significantly lower penetration through horse skin [13].

Complementary and alternative medicine (CAM) gained good acceptance in human medicine, mainly in the treatment of musculoskeletal pathologies and is now getting some popularity in veterinary medicine [14], therefore, regenerative therapies in horses may have applications for future human medicine and vice versa [10]. The initial interest and positive opinion on complementary alternative veterinary medicine (CAVM) started amongst horse owners. Most of them applied CAM therapies without the previous knowledge of their veterinarian, mainly to avoid possible conflict and fearing that their veterinarian might not want to continue providing veterinary care for their horse [14]. Some of this CAVM was supported by traditional Chinese veterinary medicine (TCVM), using acupuncture physiology to treat pain [15].

There is a lack of dissemination of traditional therapeutic procedures or rehabilitation programs using pelotherapy by key users (e.g., equine owners, equine trainers, equine veterinary, and industry) in the research field.

Equine rehabilitation programs must be designed with the previous identification of the risk factors that could predispose to musculoskeletal injury, considering the phases of healing, the rehabilitation goals, and the techniques used for acute injuries in horses [16].

The use of clays in these rehabilitation programs should fulfill the requirements regarding their safety and stability and should preferably be subjected to pre-market approval.

In this work, we characterize the mineralogical composition and technical performance of equine peloids used in prevention and rehabilitation programs. The main goals are contribution to the establishment of veterinarian clay therapeutic criteria, disclosure of the protocoled healing mixture: "clay acetic cataplasm", and to contribute to ethnoveterinary scientific databases.

\section{Materials and Methods}

\subsection{Data Preparation}

For this study, we selected seven commercial clays routinely used in veterinary medicine and suggested by the CIISA-Center for Interdisciplinary Research in Animal Health (University of Lisbon, Portugal) for the treatment of equine musculoskeletal injuries, namely front- and hind-limb tendon and ligament injuries. VET.1, VET.5, VET.6, and VET.7 are four industrial pasty clays sold in the market as an equine clay treatment to be applied in a thick layer against the lay of the hair, after intensive exercise or a competition. VET.2, VET.3, and VET.4 are natural "green" clays, sold for human application and with no specific usage recommendations.

The protocol performed by CIISA for the treatment of horse musculoskeletal limb injuries proposes a 1:10 acetic acid (AA) and piped water solution with the necessary proportion of dried "green" clay. The CIISA protocoled solution was prepared with food acetic acid, $\mathrm{pH} 2.7$ at $25^{\circ} \mathrm{C}$ resulting in a 
solution (1:10) with $\mathrm{pH}$ of 2.9 at $25^{\circ} \mathrm{C}$. This protocol solution is only applied on VET.2, VET.3, and VET.4. This resulting cataplasm must ensure adhesive proprieties when applied to the injured area. After this, the injured area is wrapped in cling film, which acts as a thermal adjuvant, prolonging the therapeutic effect of the clays. The animal is then supervised by the clinical therapist, who decides when the clay effect is assured. We compared the commercial clays' results with the protocoled healing clay and acetic acid mixture.

Clays were distributed in three groups (Table 1), Group I and Group II according to their commercial purpose, and Group III for the protocoled healing mixture. All samples were dried at $50{ }^{\circ} \mathrm{C}$, with no previous treatment, and maintained in closed containers at room temperature. For the preparation of the protocoled mixture, $10 \mathrm{~g}$ of the Group I clays was dispersed in $10 \mathrm{~mL}$ of acetic acid solution (1:10) and left to rest for 24 hours. These samples, VET.2AA, VET.3AA, and VET.4AA, were also dried at $50{ }^{\circ} \mathrm{C}$. The $\mathrm{pH}$ value of the samples was measured with a HANNA HI $9126 \mathrm{pH}$ meter, previously calibrated with standards (Titisol standard solutions) at $\mathrm{pH} 4$ and $\mathrm{pH} 7$ with an accuracy of \pm 0.05 .

Table 1. Sample identification.

\begin{tabular}{cccc}
\hline Group & Samples & Type & Commercial Purpose \\
\hline \multirow{2}{*}{ I } & VET.2 & Powder & Human dermal application \\
& VET.3 & Powder & Human dermal application \\
& VET.4 & Powder & Human dermal application \\
\hline \multirow{3}{*}{ II } & VET.1 & Paste & Equine dermal application \\
& VET.5 & Paste & Equine dermal application \\
& VET.6 & Paste & Equine dermal application \\
& VET.7 & Paste & Equine dermal application \\
\hline \multirow{2}{*}{ III $^{1}{ }^{1}$} & VET.2AA & Paste & Protocoled healing mixture \\
& VET.3AA & Paste & Protocoled healing mixture \\
& VET.4AA & Paste & Protocoled healing mixture \\
\hline \multicolumn{2}{c}{${ }^{1}$ CIISA-Center for Interdisciplinary Research in Animal Health protocol. }
\end{tabular}

\subsection{Mineralogical, Chemical, and Technological Analysis}

The mineralogical analysis was carried out by X-ray diffraction (XRD) analysis, using a Philips/Panalytical X'Pert-Pro MPD, K $\alpha \mathrm{Cu}(\alpha=1.5405 \AA$ A $)$ radiation, with $0.02^{\circ} 2 \theta \mathrm{s}^{-1}$ steps in goniometer speed. For the preparation of preferentially oriented aggregates of the clay ( $<2 \mu \mathrm{m}$ fraction), a suspension was placed on a glass slide and air dried. XRD scans were run on this air-dried glass slide, and afterward a glycerol saturation and a final heat treatment at $500^{\circ} \mathrm{C}$ were carried out [17]. The semi-quantitative identification of the principal clay minerals was obtained by measuring peak areas of the basal reflections, considering the full width at half maximum and then weighted by empirically estimated factors $[17,18]$.

The particle size distribution of these clays was determined by an X-ray beam particle size analyzer (Micromeritics Sedigraph III Plus). The samples were dried and washed with distilled water, resting for 24 hours to ensure the separation between all particles. Then, the samples were sieved $(106 \mu \mathrm{m})$ and dried. The dried sample was gently disaggregated, and the uniformity was ensured by quartile distribution. After that, $80 \mathrm{~mL}$ of sodium hexametaphosphate was added to $5.8 \mathrm{~g}$ of each sample and left to stand for 8 hours with magnetic stirring. At the end, the sample was sieved again $(106 \mu \mathrm{m})$ and submitted to ultrasound for $40 \mathrm{~s}$ before the equipment measurement step.

The chemical composition of the commercial clays was assessed by X-ray fluorescence (XRF) using a Panalytical AX-IOS PW 4400/40. Loss on ignition (LOI) was also assessed by heating $1 \mathrm{~g}$ of the sample at $1000^{\circ} \mathrm{C}$ for 1 hour in a furnace.

Abrasiveness was measured with an Einlehner AT-100 apparatus [19,20], and Atterberg limits were assessed using Casagrande Shell to obtain the liquid limit and using molding rolls in a glass plate for the plastic limit $[20,21]$. The plasticity index was calculated in accordance with the Portuguese 
standard, NP 143-1969. The expansion index test was performed by the standard LNEC E200-1967, Portuguese edition for ASTM (2008) to measure the swelling capacity of the samples when absorbing distilled water [20].

Samples were heated to $60{ }^{\circ} \mathrm{C}$ and the heat diffusiveness was assessed by a dual-channel thermometer, Lutron TM-9064. The range of time values was measured between 60 and $29^{\circ} \mathrm{C}$. Linseed oil was used to measure the oil absorption capacity of the clays. Fifteen grams of dry clay was weighed together with an amount of linseed oil. In a glass plate, linseed oil was slowly added, drop by drop, until it was possible to achieve the consistency necessary to obtain a solid roll of clay. The remaining oil and the clay roll were weighted for the oil absorption calculation.

The cation exchange capacity (CEC) was estimated by the ammonium acetate method, and the exchangeable cations $\left(\mathrm{Na}^{+}, \mathrm{K}^{+}, \mathrm{Mg}^{2+}\right.$, and $\left.\mathrm{Ca}^{2+}\right)$ were determined by an atomic absorption spectrophotometer [22]. Specific surface area (SSA) was estimated by BET analysis-Gemini II 2370.

\section{Results}

\subsection{Mineralogical and Chemical Characterization}

\subsubsection{Grain Size Distribution and Mineralogical Composition}

The results from the particle size distribution of the samples are shown in Figure 1. Group I samples contained more than $55 \%$ of fine fraction content, with an average diameter of $\sim 3 \mu \mathrm{m}$. In Group II, VET.1, VET.6, and VET.7 had around $65 \%, 68 \%$, and 79\%, respectively, of particles sized between 2 and $100 \mu \mathrm{m}$, and different average diameters, VET.1 and VET.6 had a $\mathrm{D}_{50}$ of 0.708 and $0.373 \mu \mathrm{m}$, and VET.7 had a $D_{50}$ of $1.292 \mu \mathrm{m}$. For the VET.5 sample, the granulometry size distribution was as in Group I samples, $66 \%$ of fine fraction content and an average diameter of $\sim 3 \mu \mathrm{m}$.

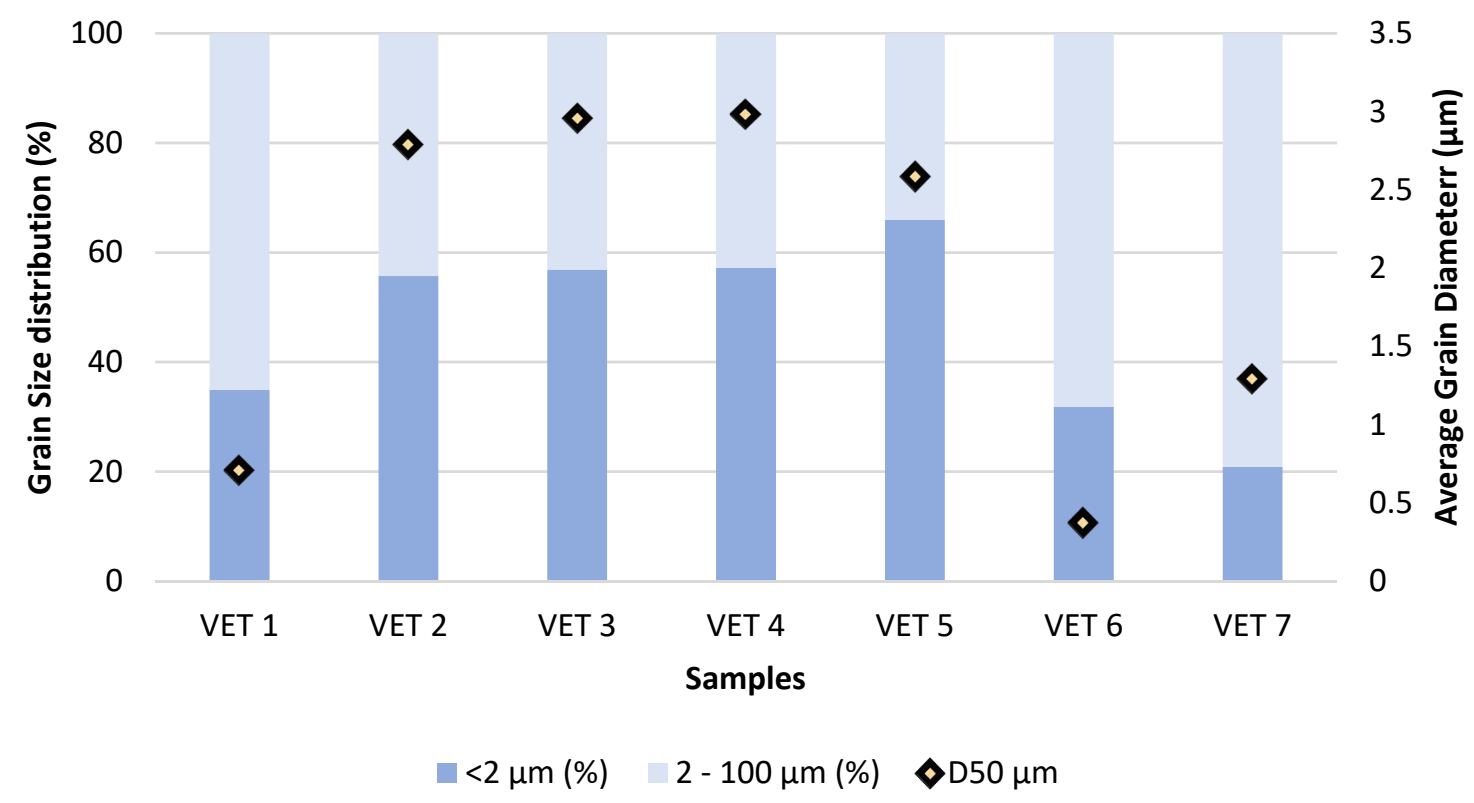

Figure 1. Grain size distribution of the Group I and Group II samples.

The mineralogical composition of the Group I and Group II clays is reported in Table 2. All samples were polymineralic (Figure 2) and exhibited differences in mineralogical composition. Considering the average for each group, we can classify Group I $(n=3)$ mineralogically as being composed by carbonates (calcite and dolomite) and silicates (quartz and phyllosilicates/clay minerals), while Group II is much richer in silicates, with a pronounced increase in phyllosilicates/clay minerals. The main clay minerals (Figure 3 ) are kaolinite (25\%) followed by illite (7\%) in Group I, and illite (68\%) followed by kaolinite (2\%) in Group II, except for VET.7 (67\% kaolinite and $28 \%$ illite). 
Courts

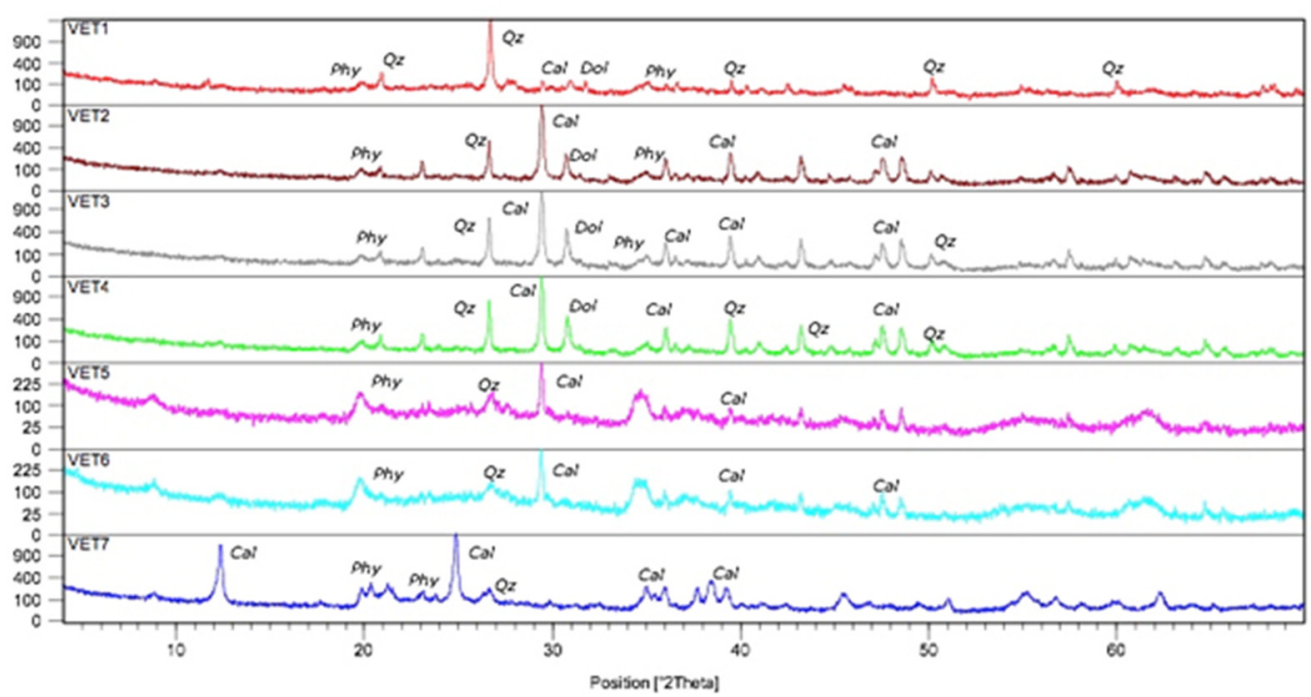

Figure 2. X-ray diffraction (Cal: calcite; Qz: quartz; Dol: dolomite; Phy: phyllosilicates).

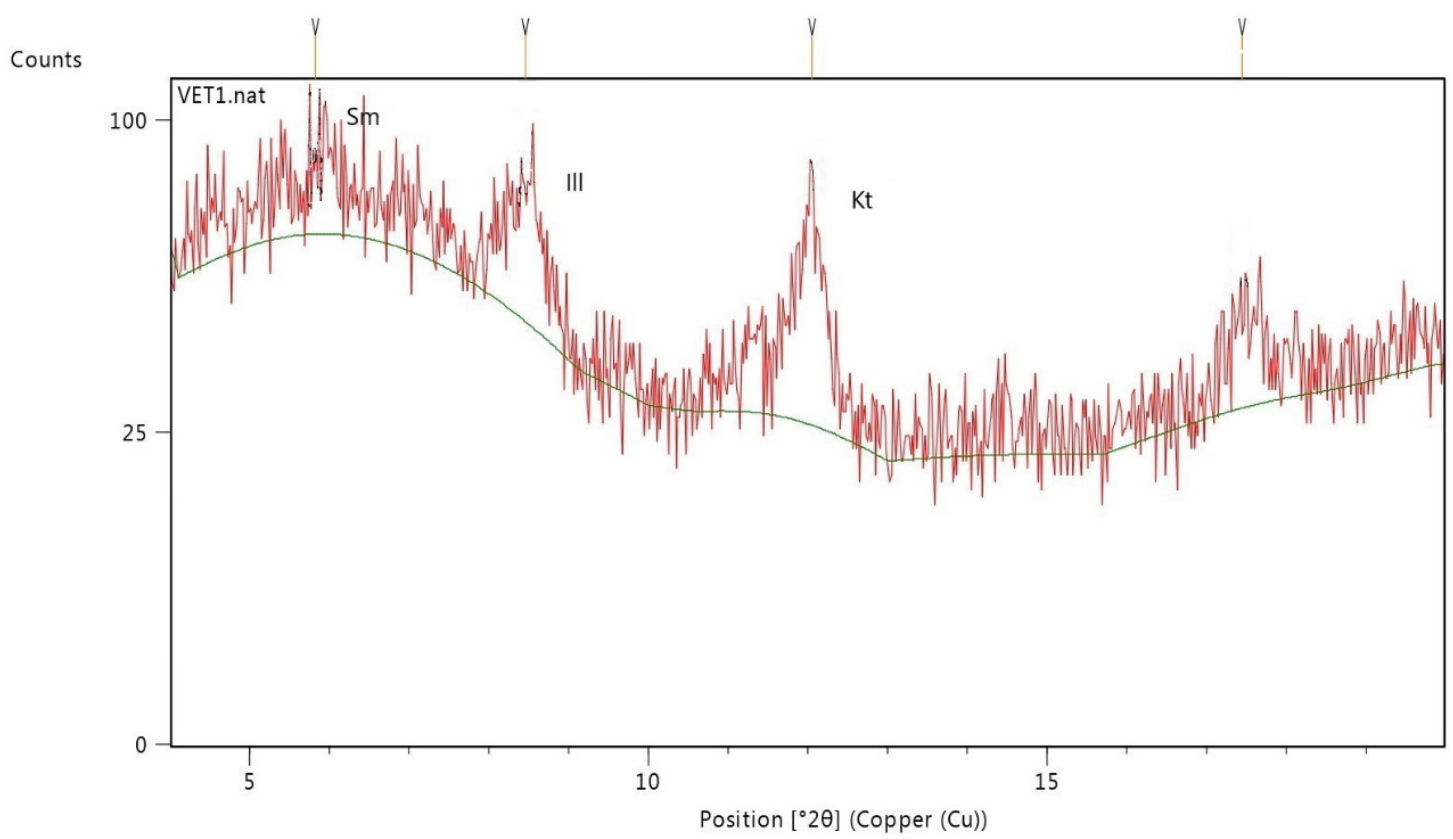

(a)

Figure 3. Cont. 


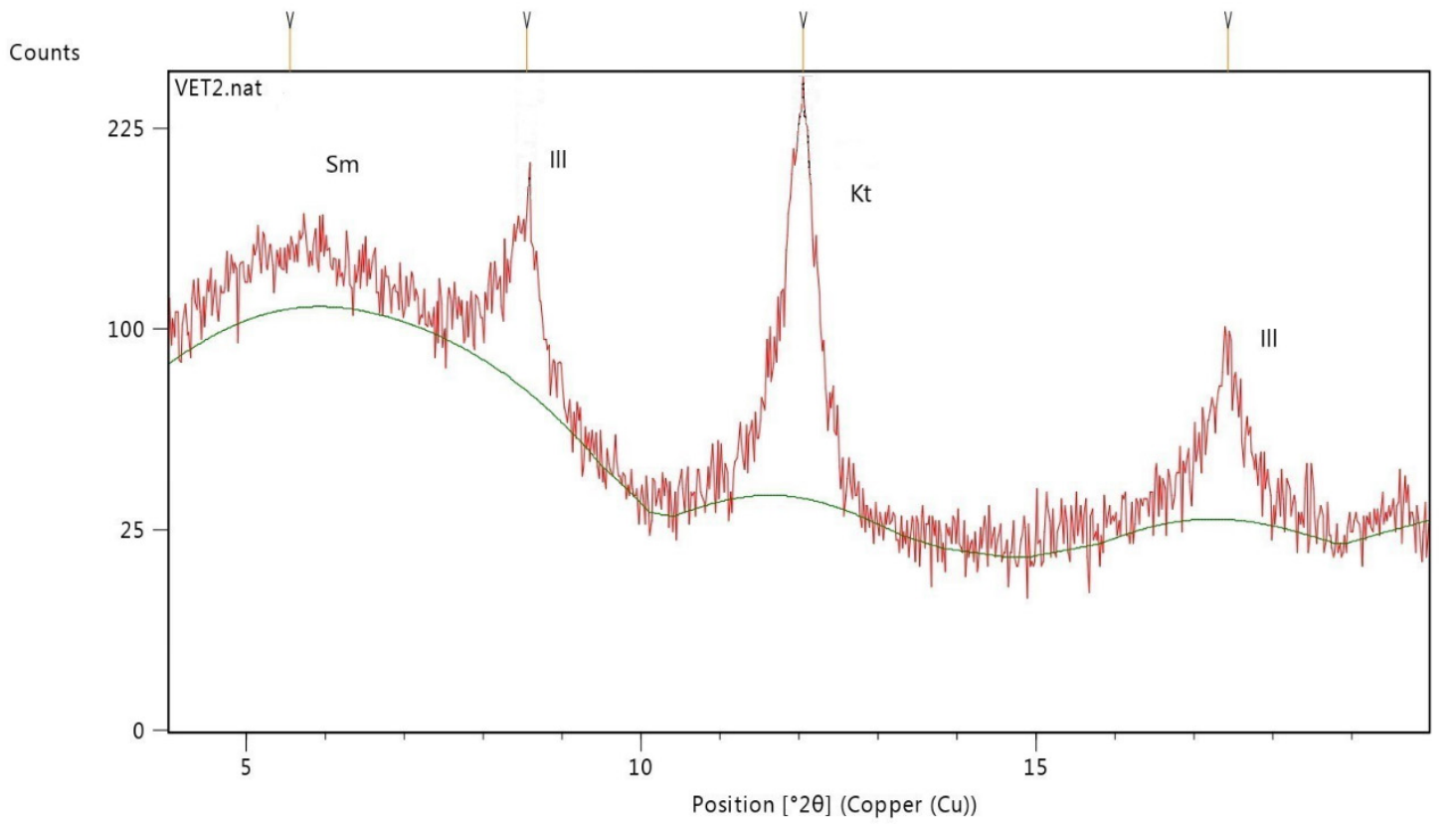

(b)

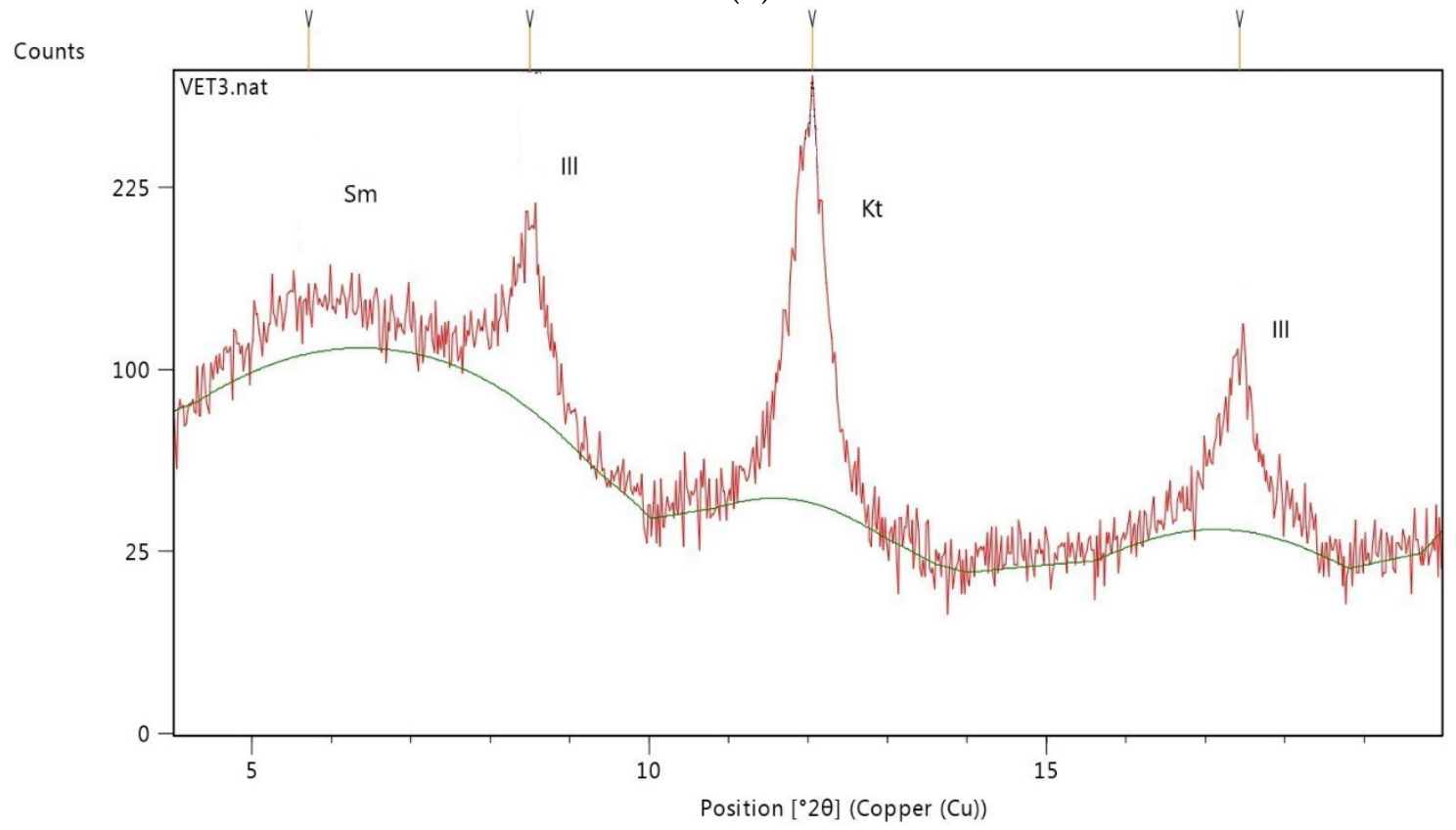

(c)

Figure 3. Cont. 




(d)

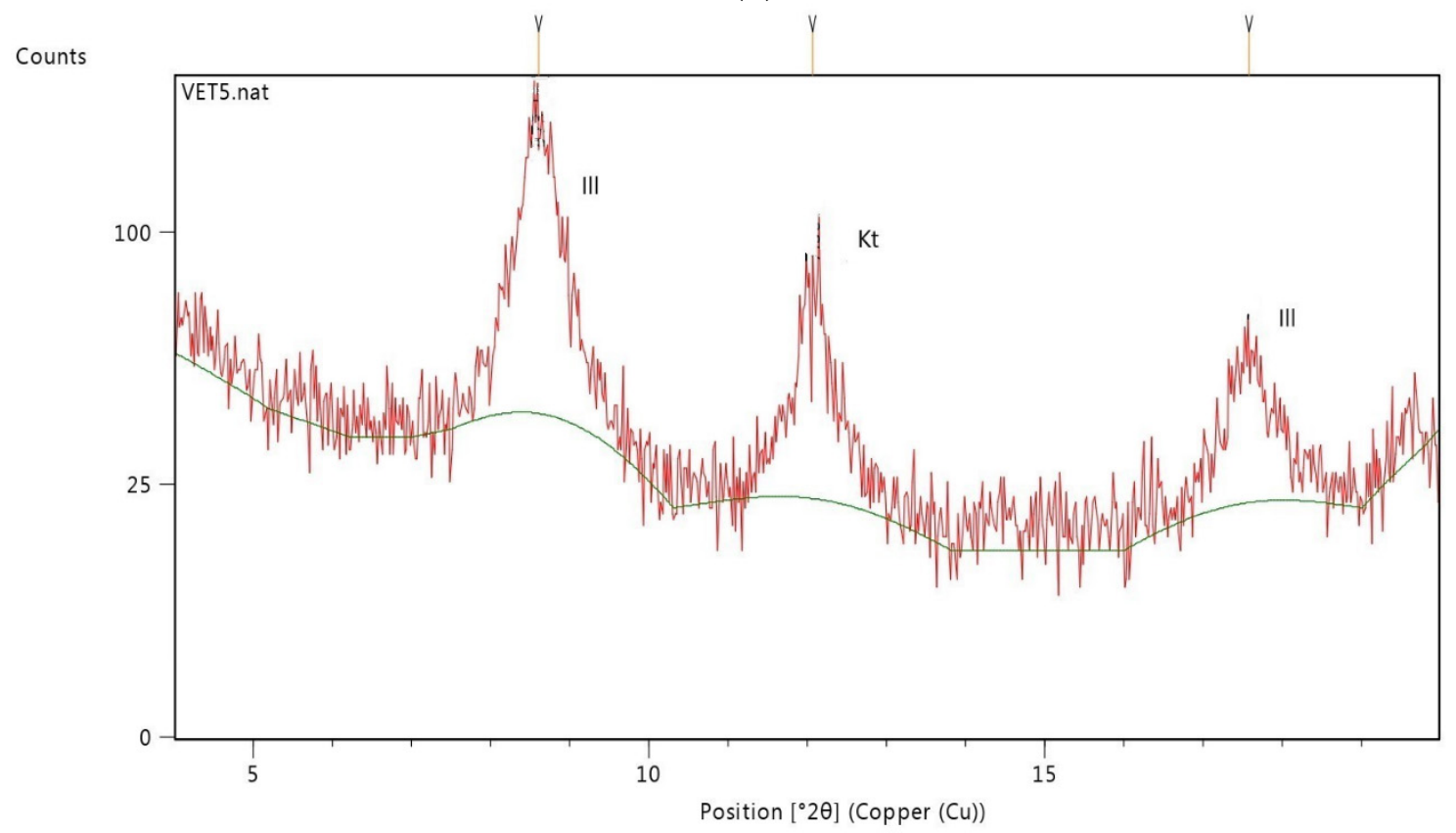

(e)

Figure 3. Cont. 


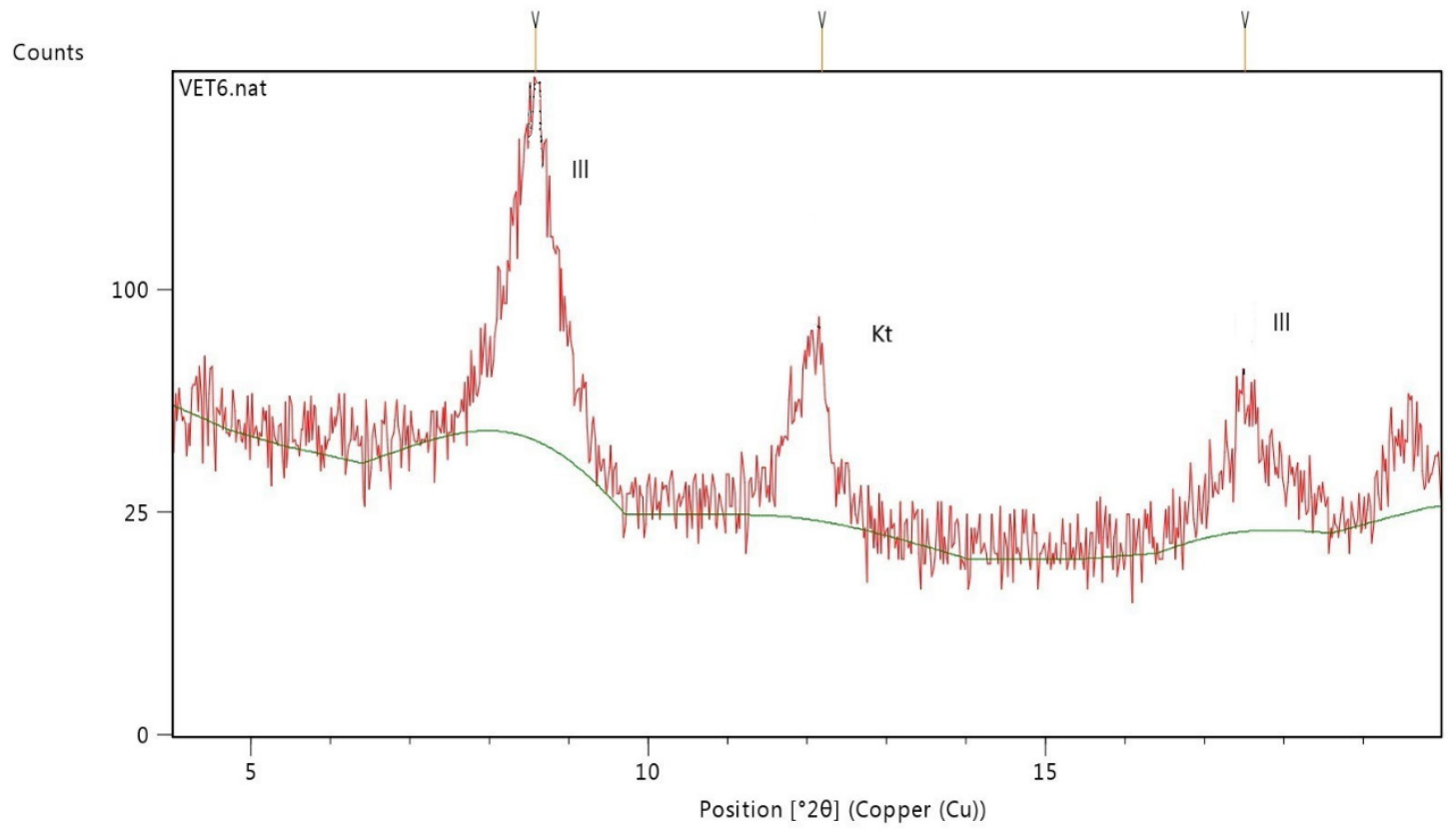

(f)

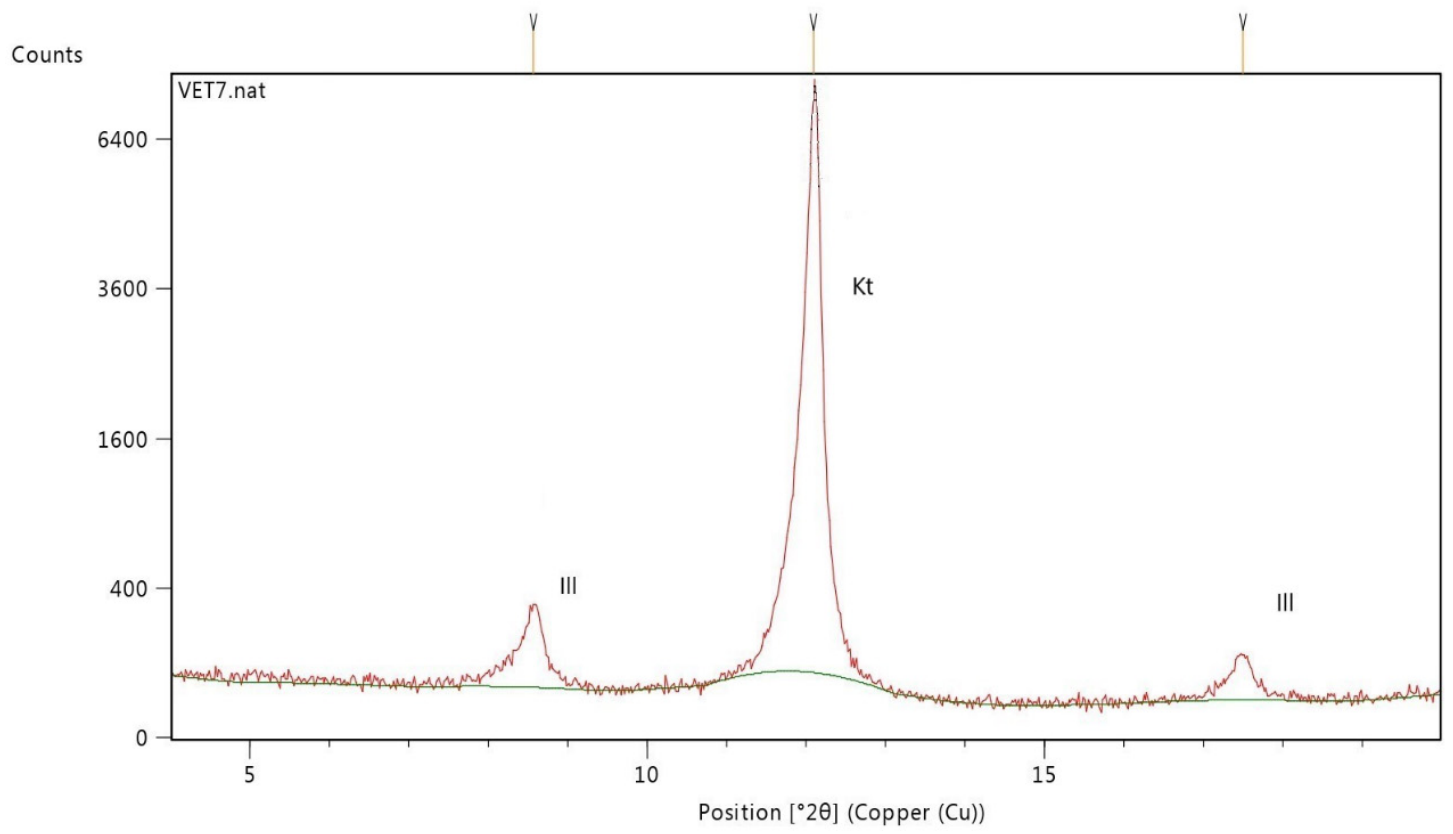

(g)

Figure 3. X-ray diffraction patterns of air-dried oriented aggregates (a) VET.1; (b) VET.2; (c) VET.3; (d) VET.4; (e) VET.5; (f) VET.6; (g) VET.7. (Ill: illite; Sm: smectite; Kt: kaolinite). 
Table 2. Mineralogical composition (\%).

\begin{tabular}{ccccccccc}
\hline & \multicolumn{4}{c}{ Total Sample (\%) } & \multicolumn{3}{c}{ Clay Minerals (\%) } \\
\hline Group & Samples & Qz & Hal & Calc & Dol & Sm & Kt & Ill \\
\hline \multirow{3}{*}{ I } & VET.2 & 6 & - & 47 & 13 & $<1$ & 29 & 5 \\
& VET.3 & 9 & - & 43 & 21 & $<1$ & 21 & 6 \\
& VET.4 & 10 & - & 39 & 17 & $<1$ & 24 & 10 \\
\hline \multirow{3}{*}{ II } & VET.1 & 44 & 2 & - & - & 1 & 3 & 50 \\
& VET.5 & 8 & - & 15 & - & - & 4 & 73 \\
& VET.6 & 3 & - & 16 & - & - & 1 & 80 \\
& VET.7 & 5 & - & - & - & - & 67 & 28 \\
\hline \multirow{2}{*}{ III } & VET.2AA & 7 & - & 52 & 16 & $<1$ & 19 & 6 \\
& VET.3AA & 14 & - & 56 & 10 & $<1$ & 17 & 3 \\
& VET.4AA & 11 & - & 58 & 11 & $<1$ & 17 & 3 \\
\hline
\end{tabular}



\subsubsection{Chemical Composition}

The content of major and minor chemical elements is shown in Table 3. Differences in chemical composition were in accordance with those detected in the mineralogical composition; Group I (the more carbonated) was richer in $\mathrm{CaO}(27 \%)$ while Group II was richer in $\mathrm{SiO}_{2}(44 \%)$ as well as in $\mathrm{Al}_{2} \mathrm{O}_{3}$, $\mathrm{Fe}_{2} \mathrm{O}_{3}$, and $\mathrm{K}_{2} \mathrm{O}$.

Table 3. Major and minor element composition of the samples. LOI = loss on ignition.

\begin{tabular}{|c|c|c|c|c|c|c|c|c|c|c|c|}
\hline \multirow{2}{*}{\multicolumn{2}{|c|}{ Samples }} & \multicolumn{3}{|c|}{ Group I } & \multicolumn{3}{|c|}{ Group III } & \multicolumn{4}{|c|}{ Group II } \\
\hline & & \multirow{2}{*}{$\begin{array}{l}\text { VET.2 } \\
24.424 \\
\end{array}$} & \multirow{2}{*}{$\begin{array}{l}\text { VET.3 } \\
26.272\end{array}$} & \multirow{2}{*}{$\begin{array}{l}\text { VET.4 } \\
24.924\end{array}$} & $\begin{array}{c}\text { VET.2 } \\
\text { AA }\end{array}$ & \multirow{2}{*}{$\begin{array}{c}\text { VET.3 } \\
\text { AA } \\
25.009\end{array}$} & \multirow{2}{*}{$\begin{array}{c}\text { VET.4 } \\
\text { AA } \\
25.499\end{array}$} & \multirow{2}{*}{$\begin{array}{l}\text { VET.1 } \\
46.078\end{array}$} & \multirow{2}{*}{$\begin{array}{l}\text { VET.5 } \\
41.723\end{array}$} & \multirow{2}{*}{$\begin{array}{l}\text { VET.6 } \\
41.110\end{array}$} & \multirow{2}{*}{$\begin{array}{l}\text { VET.7 } \\
46.206\end{array}$} \\
\hline \multirow{11}{*}{ 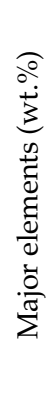 } & $\mathrm{SiO}_{2}$ & & & & 25.457 & & & & & & \\
\hline & $\mathrm{Al}_{2} \mathrm{O}_{3}$ & 10.508 & 11.147 & 10.488 & 11.062 & 10.906 & 11.120 & 15.417 & 18.195 & 17.980 & 35.098 \\
\hline & $\mathrm{Fe}_{2} \mathrm{O}_{3}$ & 2.597 & 2.957 & 2.664 & 2.885 & 2.721 & 2.916 & 6.185 & 6.423 & 6.354 & 0.778 \\
\hline & $\mathrm{MgO}$ & 3.364 & 2.742 & 3.423 & 2.334 & 2.535 & 2.415 & 2.626 & 3.129 & 3.271 & 0.427 \\
\hline & $\mathrm{CaO}$ & 26.859 & 25.976 & 27.391 & 28.636 & 27.071 & 28.811 & 4.233 & 4.901 & 5.841 & 0.049 \\
\hline & $\mathrm{Na}_{2} \mathrm{O}$ & 0.096 & 0.083 & 0.082 & 0.093 & 0.084 & 0.088 & 3.292 & 0.146 & 0.147 & 0.781 \\
\hline & $\mathrm{K}_{2} \mathrm{O}$ & 1.568 & 1.649 & 1.585 & 1.793 & 1.692 & 1.788 & 2.976 & 6.111 & 6.184 & 1.831 \\
\hline & $\mathrm{TiO}_{2}$ & 0.328 & 0.363 & 0.342 & 0.352 & 0.348 & 0.366 & 0.824 & 0.629 & 0.649 & 0.023 \\
\hline & $\mathrm{P}_{2} \mathrm{O}_{5}$ & 0.046 & 0.048 & 0.041 & 0.052 & 0.047 & 0.046 & 0.196 & 0.166 & 0.233 & 0.144 \\
\hline & $\mathrm{SO}_{3}$ & 1.295 & 1.265 & 1.219 & 1.081 & 0.998 & 1.068 & 2.239 & 0.323 & 0.029 & 0.100 \\
\hline & LOI & 28.65 & 27.20 & 27.65 & 25.96 & 28.270 & 25.550 & 13.83 & 17.85 & 17.80 & 14.3 \\
\hline \multirow{13}{*}{ 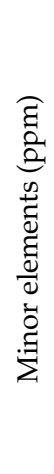 } & As* & - & • & • & • & $\bullet$ & • & 17 & 24.6 & 21.5 & 8.2 \\
\hline & $\mathrm{Cd}^{*}$ & - & - & - & - & - & • & $\bullet$ & $\bullet$ & $\bullet$ & $\bullet$ \\
\hline & $\mathrm{Pb}$ * & 13.7 & 14.4 & 12.8 & 16.1 & 14.8 & 16.1 & 31.6 & 32.2 & 31.8 & 21.6 \\
\hline & $\mathrm{Cr}$ & 51.9 & 57.4 & 53.4 & 54.6 & 52.3 & 54.8 & 130 & 68.5 & 66.7 & 4.2 \\
\hline & $\mathrm{Cu}$ & 15.4 & 8.1 & 15.0 & 8.4 & 11.6 & 11.6 & 14 & 22.2 & 24.4 & 29.5 \\
\hline & $\mathrm{Ni}$ & 16.0 & 19.7 & 16.0 & 17.7 & 15.4 & 16.1 & 33.6 & 29.0 & 29.3 & 5.0 \\
\hline & $\mathrm{Zn}$ & 24.3 & 28.2 & 26.9 & 24.3 & 23.0 & 23.2 & 95.2 & 120 & 140 & 22.3 \\
\hline & $\mathrm{Ba}$ & 110 & 120 & 150 & 160 & 150 & 110 & 250 & 280 & 200 & 150 \\
\hline & $\mathrm{Co}$ & - & 7.5 & 4.9 & 5.5 & 6.1 & 4.8 & 14.7 & 10.2 & 11.7 & $\bullet$ \\
\hline & $\mathrm{Sr}$ & 230 & 220 & 200 & 240 & 220 & 240 & 210 & 180 & 280 & 160 \\
\hline & V & 59.7 & 74.5 & 72.4 & 57.2 & 56.4 & 57.7 & 100 & 72.2 & 78.1 & 5.4 \\
\hline & $\mathrm{Sb}^{*}$ & $\bullet$ & $\bullet$ & $\bullet$ & $\bullet$ & $\bullet$ & $\bullet$ & $\bullet$ & $\bullet$ & $\bullet$ & $\bullet$ \\
\hline & $\mathrm{Sc}$ & 19.8 & 18.6 & 17.1 & 20.6 & 17.9 & 21.0 & 10.9 & 10.1 & 11.2 & • \\
\hline
\end{tabular}

- Not determined; * Potentially toxic elements.

Considering the chemical elements that are potentially toxic and not allowed in care products (Regulation (EC) 1223/2009), the Group II exhibited the highest values for $\mathrm{As}, \mathrm{Pb}, \mathrm{Cr}, \mathrm{Ni}$, and $\mathrm{Zn}$ when compared with Group I, for human usage. 
Group II shows high levels of $\mathrm{Pb}$ and $\mathrm{As}$, however, it is difficult to estimate equine exposure and the health risks associated.

\subsection{Physical and Technological Characterization}

Both groups show low cation exchange capacities and exchange mainly $\mathrm{Ca}^{2+}$, with the exception of VET.1 and VET.7, which highlight also $\mathrm{Na}^{+}$; and VET.5 and VET.6, which have $\mathrm{K}^{+}$, as an exchangeable main cation (Tables 4 and 5). They have good plasticity, which is necessary to ensure adhesiveness to the skin. For Group I and VET.1, an abrasiveness action is expected when in contact with the skin surface, but the impact depends on the skin condition of the animal and horsehair protection.

Table 4. Main physical and technological properties of the studied samples.

\begin{tabular}{ccccccccc}
\hline \multirow{2}{*}{ Group } & \multirow{2}{*}{ Samples } & \multirow{2}{*}{ P.I. (\%) } & A.I. $\left(\mathbf{g} / \mathbf{m}^{\mathbf{2}}\right)$ & C.E.C. $(\mathbf{m e q} / \mathbf{1 0 0})$ & \multicolumn{4}{c}{ E.C. $(\mathbf{m g} / \mathbf{L})$} \\
\cline { 7 - 10 } & & & & & $\mathbf{N a}$ & $\mathbf{M g}$ & $\mathbf{K}$ & Ca \\
\hline \multirow{3}{*}{ I } & VET.2 & 25 & 142.85 & 7 & 1.67 & 25.28 & 9.63 & 730.81 \\
& VET.3 & 26 & 236.77 & 7 & 1.79 & 27.76 & 7.45 & 734.50 \\
& VET.4 & 25 & 140.21 & 7 & 1.36 & 26.53 & 7.11 & 699.98 \\
\hline \multirow{3}{*}{ II } & VET.1 & n.d. & 353.17 & 19 & 240.68 & 63.90 & 51.38 & 568.39 \\
& VET.5 & 34 & 26.45 & 10 & 2.56 & 27.10 & 110.51 & 724.47 \\
& VET.6 & 29 & 31.75 & 12 & 3.16 & 16.76 & 159.74 & 724.28 \\
& VET.7 & 18 & 6.61 & 3 & 315.12 & 5.22 & 8.19 & 11.74 \\
\hline \multirow{3}{*}{ III } & VET.2AA & n.d. & n.d. & 6 & 1.38 & 23.18 & 8.96 & 680.83 \\
& VET.3AA & n.d. & n.d. & 7 & 1.37 & 20.77 & 8.29 & 572.56 \\
& VET.4AA & n.d. & n.d. & 5 & 1.50 & 21.46 & 8.79 & 584.11 \\
\hline
\end{tabular}

n.d.-not determined; P.I.-plasticity index; A.I.-abrasivity index; C.E.C.—cation exchange capacity; E.C.- - exchange cations.

Table 5. Main physical and technological properties of the studied samples (Cont.).

\begin{tabular}{|c|c|c|c|c|c|c|}
\hline Group & Samples & C.K. (min) & O.A. (\%) & $\mathrm{pH}$ & Exp. (\%) & S.S.A. $\left(\mathrm{m}^{2} / \mathrm{g}\right)$ \\
\hline \multirow{3}{*}{ I } & VET.2 & 13.6 & 29 & 7.0 & 19.5 & 22.50 \\
\hline & VET.3 & 19.0 & 30 & 7.3 & 12.3 & 22.58 \\
\hline & VET.4 & 19.4 & 31 & 7.7 & 14.8 & 22.11 \\
\hline \multirow{4}{*}{ II } & VET.1 & 18.4 & 43 & 6.8 & 17.8 & 13.75 \\
\hline & VET.5 & 37.8 & 37 & 7.3 & 13.6 & 42.55 \\
\hline & VET.6 & 30.1 & 37 & 7.7 & 10.9 & 44.71 \\
\hline & VET.7 & 30.3 & 63 & 8.6 & 3.1 & 5.09 \\
\hline \multirow{3}{*}{ III } & VET.2AA & n.d. & n.d. & 7.6 & n.d. & n.d. \\
\hline & VET.3AA & n.d. & n.d. & 7.8 & n.d. & n.d. \\
\hline & VET.4AA & n.d. & n.d. & 7.8 & n.d. & n.d. \\
\hline
\end{tabular}

\section{Discussion}

These two groups of clays recommended by the CIISA-Center for Interdisciplinary Research in Animal Health, University of Lisbon, for the treatment of horse musculoskeletal injuries, have different compositional and textural characteristics.

Considering application and topical use characteristics (Table 6), taking as reference recommended values published by several authors $[8,19,20,22-34]$, the samples studied show good plastic properties, which are necessary for skin adherence; good oil absorptive capabilities, which is important to clean the skin from impurities or wound secretions; and Group II has a good heat retention capacity, important when it is necessary to heat the cataplasm, to active the blood circulation. The abrasiveness of Group I clays, which can cause unnecessary rubbing on the animal's injured skin, should be smoothed. 
Table 6. Veterinary clay group characterizations.

\begin{tabular}{|c|c|c|c|c|c|c|c|}
\hline Properties & VET.1 & VET.2 & VET.3 & VET.4 & VET.5 & VET.6 & VET.7 \\
\hline $\begin{array}{l}\text { Adhesiveness } \\
{[17,18,20,22,29,31]}\end{array}$ & $\Delta$ & $\Delta$ & $\Delta$ & $\Delta$ & $\Delta$ & $\Delta$ & $\bullet$ \\
\hline $\begin{array}{l}\text { Abrasiveness } \\
{[17,18,20-22,29,31,32]}\end{array}$ & $\nabla$ & $\nabla$ & $\nabla$ & $\nabla$ & $\Delta$ & $\Delta$ & $\boldsymbol{\Delta}$ \\
\hline $\begin{array}{l}\text { Hazardous elements } \\
{[20,23,28,31,32]}\end{array}$ & $\nabla$ & $\Delta$ & $\Delta$ & $\Delta$ & $\nabla$ & $\nabla$ & $\nabla$ \\
\hline $\begin{array}{l}\text { Essential elements } \\
{[20,21,30-32]}\end{array}$ & $\begin{array}{c}\mathbf{\Delta} \\
\mathrm{Ca}^{2+} \\
\mathrm{Na}^{+}\end{array}$ & $\underset{\mathrm{Ca}^{2+}}{\mathbf{\Delta}}$ & $\mathrm{Ca}^{2+}$ & $\underset{\mathrm{Ca}^{2+}}{\mathbf{4}}$ & $\begin{array}{c}\mathrm{Ca}^{2+}, \\
\mathrm{K}^{+}\end{array}$ & $\begin{array}{c}\mathrm{Ca}^{2+}, \\
\mathrm{K}^{+}\end{array}$ & $\underset{\mathrm{Na}^{+}}{\mathbf{4}}$ \\
\hline $\begin{array}{l}\text { Oil Absorption } \\
{[18,20-22,31,32]}\end{array}$ & $\Delta$ & $\boldsymbol{\Delta}$ & $\boldsymbol{\Delta}$ & $\Delta$ & $\Delta$ & $\Delta$ & $\Delta$ \\
\hline $\begin{array}{l}\text { Heat Retention } \\
{[18,20,21,27,31,32]}\end{array}$ & $\Delta$ & • & $\bullet$ & $\bullet$ & $\Delta$ & $\Delta$ & $\Delta$ \\
\hline $\begin{array}{l}\text { Antibacterial performance } \\
{[6,24-26]}\end{array}$ & $\nabla$ & $\underset{\text { VET.2AA }}{\Delta}$ & $\stackrel{\Delta}{\text { VET.3AA }}$ & $\stackrel{\Delta}{\text { VET.4AA }}$ & $\boldsymbol{\nabla}$ & $\nabla$ & $\boldsymbol{\nabla}$ \\
\hline
\end{tabular}

$\Delta$ Advisable; $\bullet$ Advisable with limitations; $\mathbf{v}$ Needs vigilance.

Calcium is an essential element that is important for the growth and regeneration of collagenous bone-cartilage and this may explain the traditionally used "green" carbonated clay for the acetic acid cataplasm formulation. Despite As and $\mathrm{Pb}$ being technically avoidable above 0.5 and $2.0 \mathrm{mg} / \mathrm{kg}$ [25], respectively, the fact that they are above the risk limit that is internationally accepted for pharmaceutical formulations and cosmetics applied to human beings, and that several factors should be considered in transdermal penetration for humans and for horses, the same formulation may have different efficacies and safety profiles when used in species for which they were not developed [13]. Group II are clays that were industrially developed specifically for equine usage.

The addition of acetic acid (Group III) does not reveal any significant chemical changes when compared with Group I, apart from the $\mathrm{pH}$ that becomes more alkaline (closer to 8). All samples have a pH around 7 and 8. Organic acids (e.g., acetic acid) are usually used in food as natural preservatives and antibacterial agents. The manipulation of clay minerals to eliminate clinical and environmental bacteria is very common and the investigation of the antibacterial properties of natural clays has taken a new approach $[8,26-28]$, where the possibility of incorporating bactericidal properties into clays may also be activated by the use of an acid solution in the treatment [27]. Some studies reveal the strong antibacterial effect of acetic acid combined with silver nanoparticles (AgNPS), where the release of $\mathrm{Ag}^{+}$ responsible for the antibacterial activity increased by the addition of acetic acid [28].

The obtained data, when analyzed in comparison to reference values, allowed us to consider that both groups are adequate for therapeutic proposes, such as the treatment of horse musculoskeletal injuries, but Group II shows the best characteristics. Group II, having a prior industrial preparation, is technologically adapted for use in horses. The use of additives and preservatives in their preparation may be the reason why they are less abrasive and toxic.

The establishment of a health database considering ethnoveterinary medicine studies may enrich the equine health databases, useful to institutions, veterinarians, animal owners, and also providing guidelines for the investigation of new therapies and for scientific evidence findings.

\section{Conclusions}

The potential benefit of using therapeutic clays in equine lameness injuries is to minimize the side-effects associated with oral and intra-articular administration of anti-inflammatory medicines and to sustain a local release of therapeutic elements. This study can also be considered as a contribution to a major database of clays used for animal topical application, to the awakening of traditional and ancestral methodologies in healing clay preparations, and also to the knowledge about the contribution of these clays in the rehabilitation programs developed by veterinarians. 
Through this study we tried to address the knowledge gaps about the mineralogical and chemical composition of clays used for equine peloid preparation and assessed their technical performance. This research assured that the studied clays fulfill the safety and stability requirements for these rehabilitation programs, thus, enabling them to be submitted for pre-market technical and legal approval process.

The main limitation of this study was the impossibility to correlate CIISA therapeutic formulation results with results obtained with specific equine commercial clays. Further work is needed to compare the antibacterial effectiveness of this protocol with other mud cataplasm protocols applied to horses and humans. This would be important and necessary for the establishment of healing criteria for veterinary clays.

Most of the thermal spas around the world recommend their own mud baths or local mud cataplasm applications, as they recognize therapeutic results through their anti-inflammatory, analgesic, and antiseptic effects on musculoskeletal and dermatologic pathologies, which are increasingly supported by clinical trials. The efficacy of the candidate clays to be used in veterinary pelotherapy should be evaluated and compared with human pelotherapy results and supported by clinical trials.

The safety and regulatory compliance of these products should also be a priority. The identification of unwanted trace elements or toxic substances based on the raw material source (natural or synthetic) should be a determinant for market surveillance of the appropriate limits expected in these natural products.

Author Contributions: Conceptualization, C.M.B.; methodology C.M.B. and F.R.; resources, C.M.B., Â.C., D.T. and C.S.; investigation, C.M.B., F.R. and P.T.; project administration, C.M.B.; writing-original draft preparation, C.M.B.; writing-review and editing, C.M.B. and F.R.; supervision, F.R. All authors have read and agreed to the published version of the manuscript.

Funding: This research was funded by FCT—Fundação para a Ciência e a Tecnologia and Exatronic, Lda, grant number SFRH/BDE/11062/2015 and also supported by GeoBioTec Research Center (UIDB/04035/2020), funded by FCT, FEDER funds through the Operational Program Competitiveness Factors-COMPETE.

Acknowledgments: We are grateful to CIISA-Center for Interdisciplinary Research in Animal Health, University of Lisbon, for the samples used for experiments.

Conflicts of Interest: The authors declare no conflict of interest.

\section{References}

1. Gomes, C. Healing and edible clays: A review of basic concepts, benefits and risks. Environ. Geochem. Health 2018, 40, 1739-1765. [CrossRef]

2. Williams, B.W. Natural antibacterial clays: Historical uses and modern advances. Clays Clay Miner. 2019, 67, 7-24. [CrossRef]

3. González, J.A.; Amich, F.; Postigo-Mota, S.; Vallejo, J.R. The use of wild vertebrates in contemporary Spanish ethnoveterinary medicine. J. Ethnopharmacol. 2016, 191, 135-151. [CrossRef] [PubMed]

4. Slamova, R.; Trckova, M.; Vondruskova, H.; Zraly, Z.; Pavlik, I. Clay minerals in animal nutrition. Appl. Clay Sci. 2011, 51, 395-398. [CrossRef]

5. Pieszka, M.; Łuszczyński, J.; Hedrzak, M.; Goncharova, K.; Pierzynowski, S.G. The efficacy of kaolin clay in reducing the duration and severity of "heat" diarrhea in foals. Turk. J. Vet. Anim. Sci. 2016, 40, 323-328. [CrossRef]

6. López-Galindo, A.; Viseras, C.; Cerezo, P. Compositional, technical and safety specifications of clays to be used as pharmaceutical and cosmetic products. Appl. Clay Sci. 2007, 36, 51-63. [CrossRef]

7. Carretero, M.I.; Pozo, M. Clay and non-clay minerals in the pharmaceutical industry. Part I. Excipients and medical applications. Appl. Clay Sci. 2009, 46, 73-80. [CrossRef]

8. Williams, L.B.; Haydel, S.E. Evaluation of the medicinal use of clay minerals as antibacterial agents. Int. Geol. Rev. 2010, 52, 745-770. [CrossRef]

9. Londono, S.C.; Williams, L.B. Unraveling the antibacterial mode of action of a clay from the Colombian Amazon. Environ. Geochem. Health 2015, 38, 363-379. [CrossRef] 
10. Spaas, J.H.; Guest, D.J.; Van de Walle, G.R. Tendon regeneration in human and equine athletes. Sports Med. 2012, 42, 871-890. [CrossRef]

11. Kaabar, W.; Gundogdu, O.; Tzaphlidou, M.; Janousch, M.; Attenburrow, D.; Bradley, D.A. Investigation of essential element distribution in the equine metacarpophalangeal joint using a synchrotron radiation micro x-ray fluorescence technique. In Proceedings of the National Physics Conference 2007_PERFIK 2007, Kuala Terengganu, Malaysia, 26-28 December 2007; Volume 25, pp. 18-24. [CrossRef]

12. Soma, L.R.; Uboh, C.E.; Maylin, G.M. The use of phenylbutazone in the horse. J. Vet. Pharmacol. Ther. 2012, 35, 1-12. [CrossRef] [PubMed]

13. Andreeta, A.; Verde, C.; Babusci, M.; Muller, R.; Simpson, M.I.; Landoni, M.F. Comparison of diclofenac diethylamine permeation across horse skin from five commercial medical human formulations. J. Equine Vet. Sci. 2011, 31, 502-505. [CrossRef]

14. Bergenstrahle, A.; Nielsen, B.D. Attitude and behavior of veterinarians surrounding the use of complementary and alternative veterinary medicine in the treatment of equine musculoskeletal pain. J. Equine Vet. Sci. 2016, 45, 87-97. [CrossRef]

15. Robinson, N.G. Making sense of the metaphor: How acupuncture works neurophysiologically. J. Equine Vet. Sci. 2009, 29, 642-644. [CrossRef]

16. Davies, L. Equine rehabilitation. In Pain Management in Veterinary Practice, 1st ed.; Egger, C.M., Love, L., Doherty, T., Eds.; John Wiley \& Sons: Hoboken, NJ, USA, 2013; Volume 1, pp. 1-464. [CrossRef]

17. Oliveira, A.; Rocha, F.; Rodrigues, A.; Jouanneau, J.; Dias, J.; Weber, O.; Gomes, C. Clay minerals from the sedimentary cover from the Northwest Iberian shelf. Prog. Oceanogr. 2002, 52, 233-247. [CrossRef]

18. Galhano, C.; Rocha, F.; Gomes, C. Geostatistical analysis of the influence of textural, mineralogical and geochemical parameters on the geotechnical behaviour of the "Argilas de Aveiro" Formation (Portugal). Clay Miner. 1999, 34, 109-116. [CrossRef]

19. Quintela, A.; Costa, C.; Terroso, D.; Rocha, F. Abrasiveness index of dispersions of Portuguese clays using the Einlehner method: Influence of clay parameters. Clay Miner. 2014, 49, 27-34. [CrossRef]

20. Rebelo, M.; Viseras, C.; Galindo, A.L.; Rocha, F.; Silva, E.F. Rheological and thermal characterization of peloids made of selected Portuguese geological materials. Appl. Clay Sci. 2011, 52, 219-227. [CrossRef]

21. Quintela, A.; Costa, C.; Terroso, D.; Rocha, F. Liquid limit determination of clayey material by Casagrande method, fall cone test and EBS parameter. Mater. Technol. Adv. Perform. Mat. 2014, 29, 82-87. [CrossRef]

22. Rebelo, M.; Rocha, F.; Ferreira da Silva, E. Mineralogical and physicochemical characterization of selected Portuguese Mesozoic-Cenozoic muddy/clayey raw materials to be potentially used as healing clays. Clay Miner. 2010, 45, 229-240. [CrossRef]

23. Quintela, A.; Terroso, D.; Ferreira da Silva, E.; Rocha, F. Certification and quality criteria of peloids in use for therapeutic purposes. Clay Miner. 2012, 47, 441-451. [CrossRef]

24. Quintela, A.; Terroso, D.; Costa, C.; Sá, H.; Nunes, J.C.; Rocha, F. Characterization and evaluation of hydrothermally influenced clayey sediments from Caldeiras da Ribeira Grande fumarolic field (Azores Archipelago, Portugal) used for aesthetic and pelotherapy purposes. Environ. Earth Sci. 2015, 73, 2833-2842. [CrossRef]

25. Bund, B.V.L. Technically avoidable heavy metal contents in cosmetic products. J. Consum. Prot. Food Saf. 2017, 12, 51-53. [CrossRef]

26. Kalfa, A.; Rakovitsky, N.; Tavassi, M.; Ryskin, M.; Ben-Ari, J.; Etkin, H.; Shuali, U.; Nir, S. Removal of Escherichia coli and total bacteria from water by granulated micelle-clay complexes: Filter regeneration and modeling of filtration kinetics. Appl. Clay Sci. 2017, 147, 63-68. [CrossRef]

27. Santos, M.F.; Oliveira, C.M.; Tachinski, C.T.; Fernandes, M.P.; Pitch, C.T.; Angioletto, E.; Riella, H.G.; Fiori, M.A. Bactericidal properties of bentonite treated with Ag+ and acid. Int. J. Miner. Process. 2011, 100, 51-53. [CrossRef]

28. Sedira, S.; Ayachi, A.A.; Lakehal, S.; Fateh, M.; Achour, S. Silver nanoparticles in combination with acetic acid and zinc oxide quantum dots for antibacterial activities improvement-A comparative study. Appl. Surf. Sci. 2014, 311, 659-665. [CrossRef]

29. García-Villén, F.; Sánchez-Espejo, R.; Carazo, E.; Borrego-Sánchez, A.; Aguzzi, C.; Cerezo, P.; Viseras, C. Characterization of Andalusian peats for skin health care formulations. Appl. Clay Sci. 2017, 160, 201-205. [CrossRef] 
30. Bocca, B.; Pino, A.; Alimonti, A.; Forte, G. Toxic metals contained in cosmetics: A status report. Regul. Toxicol. Pharmacol. 2014, 68, 447-467. [CrossRef]

31. Pozo, M.; Carretero, M.I.; Maraver, F.; Pozo, E.; Gómez, I.; Armijo, F.; Rubí, J.A.M. Composition and physico-chemical properties of peloids used in Spanish spas: A comparative study. Appl. Clay Sci. 2013, 83-84, 270-279. [CrossRef]

32. Fernández-González, M.V.; Martín-García, J.M.; Delgado, G.; Párraga, J.; Delgado, R. A study of the chemical, mineralogical and physicochemical properties of peloids prepared with two medicinal mineral waters from Lanjarón Spa (Granada, Spain). Appl. Clay Sci. 2013, 80-81, 107-116. [CrossRef]

33. Costa, C.; Fortes, A.; Rocha, F.; Cerqueira, A.; Santos, D.; Amaral, M.H. Characterization of Portuguese gypsums as raw materials for Dermocosmetics. Clay Miner. 2019, 54, 277-281. [CrossRef]

34. Cerqueira, A.; Costa, C.; Sequeira, C.; Terroso, D.; Rocha, F. Assessment of clayey materials from Santa Maria Island (Azores, Portugal) for peloids preparation. Clay Miner. 2019, 54, 299-307. [CrossRef]

(C) 2020 by the authors. Licensee MDPI, Basel, Switzerland. This article is an open access article distributed under the terms and conditions of the Creative Commons Attribution (CC BY) license (http://creativecommons.org/licenses/by/4.0/). 